\title{
CHRONIC LOW GRADE INFLAMMATION IN AGING PROCESS AS A LINK ON A CHAIN OF OBESITY - RELATED VASCULAR DISORDERS
}

\section{HRONIČNA NISKOSTEPENA INFLAMACIJA U PROCESU STARENJA KAO KARIKA U LANCU VASKULARNIH POREMEĆAJA KOJI SU POVEZANI SA GOJAZNOŚĆU}

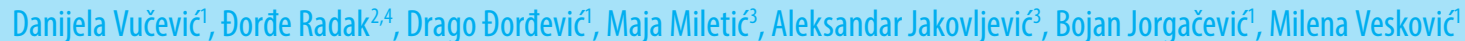

\section{Summary}

The pathogenesis of obesity-related vascular disorders has not been fully elucidated. The fundamental role of inflammation in aging process is now widely recognized, particularly for atherosclerotic disease which begins before birth. The number of obese individuals worldwide has reached two billion, leading to an explosion of obesity-related vascular disorders associated with increased morbidity and mortality. Obesity, as a chronic low grade inflammatory process, is important risk factor for metabolic and cardiovascular disease. Despite a well-known genetic component, this risk appears to originate from several abnormalities in adipose tissue function associated with a chronic inflammatory state. In particular, obesity as the most common nutritional disorder in industrialized countries, is closely related to impaired endothelial function, a well-known marker of preatherosclerotic disease. These conditions disrupt vascular homeostasis by causing an imbalance between the nitric oxide pathway and the endothelin-1 system, with impaired insulin-stimulated endothelium-dependent vasodilation. Having in mind the growing population of overweight and obese people worldwide, along with an increasingly aging population, understanding the pathophysiology of obesity on cardiovascular system is essential. The mechanisms linking obesity-related vascular disorders and low grade inflammation in aging process are the focus of this paper.

Keywords: inflammation, aging, obesity-related vascular disorders, insulin resistance, adipokines

\section{Sažetak}

Patogeneza vaskularnih poremećaja koji su povezani sa gojaznošću nije u potpunosti razjăšnjena. Danas je poznata fundamentalna uloga inflamacije u procesu starenja, naročito kod aterosklerozne bolesti, koja počinje pre rođenja. Broj gojaznih osoba širom sveta je dostigao cifru dva biliona i doveo do "eksplozije" vaskularnih poremećaja koji su povezani sa gojaznošću i povećanim morbiditetom i mortalitetom. Gojaznost, kao hronični niskostepeni inflamacijski proces, je važan faktor rizika za nastanak metaboličkih i kardiovaskularnih bolesti. Pored dobro proučene genetske komponente, izgleda da je za ovaj rizik zaslužno i nekoliko poremećaja funkcije masnog tkiva koji se dovode u vezu sa stanjem hronične inflamacije. U tom smislu prednjači gojaznost, pošto je kao najčešći poremećaj ishrane u razvijenim zemljama blisko povezana sa endotelnom disfunkcijom, koja predstavlja uveliko poznat marker preaterosklerozne bolesti. Takvi uslovi narušavaju vaskularnu homeostazu, dovodeći do dizbalansa između metaboličkog puta azot monoksida i sistema endotelina-1, što je praćeno otežanim odvijanjem insulinom podstaknute vazodilatacije. Imajući u vidu globalni zajednički porast broja kako osoba sa viškom kilograma i gojaznih osoba, tako i starije populacije, razumevanje patogeneze gojaznosti i njenog uticaja na kardiovaskularni sistem je od esencijalnog značaja. Mehanizmi koji čne sponu između vaskularnih poremećaja povezanih sa gojaznošću i niskostepene inflamacije u procesu starenja nalaze se u fokusu ovog rada.

Ključne reči: inflamacija, starenje, vaskularni poremećaji povezani sa gojaznošću, insulinska rezistencija, adipokini

\section{INTRODUCTION}

Discovery consists of seeing what everybody has seen and thinking what nobody has thought /Albert Szent-Gyorgyi/.

Inflammatory process is a part of the host immune defenses to pathogens and tissue responses to injury. Inflammatory reactions engage and operate at all levels of biological organization, from free radicals to behavior (1). Inflammation may be considered a core process of human aging because of its involvement in baseline aging and in the major degenerative diseases of later life, atherosclerosis, Alzheimer's disease and cancer (2). Blood levels of C-reactive protein (CRP), interleukin-6 (IL-6) and other proinflammatory cytokines are risk indicators of cardiovascular events and mortality (3). Even in the absence of specific pathological lesions, inflammatory gene expression increases during aging in humans and animal models $(1,3)$.

The acute phase of inflammation largely involves the innate immune responses, whereas subsequent phases may include adaptive immune responses of antigen-selected $\mathrm{T}$ and $\mathrm{B}$ cells, but with continuing mediation by various innate immune factors (1). Because tissue 
damage activates gene responses shared with the acute phase, most degenerative diseases of aging involve innate immune responses. Thus, it is very difficult to resolve cause and effect in the slow inflammatory processes that may be shared across tissues during chronic degenerative diseases of aging (1-3). Besides, foci of chronic inflammation also typically stimulate local cell proliferation, which in some instances progresses to cellular (proliferative) senescence $(1,4-6)$.

Obesity is understood as a proinflammatory state with chronic activation of acute phase responses (7-9). Blood CRP and IL- 6 are strongly correlated with the degree of obesity across a broad range of the body mass index (BMI) (10). White adipose depots contain numerous macrophages, which secrete proinflammatory cytokines (11). Visceral fat in particular secretes adipokines and IL-6 (12). Adipocytes from diabetics show increased cytokine production, telomere shortening and other markers of senescence (13). The increased blood inflammatory profile in obesity is linked to insulin resistance (IR), diabetes, cardiovascular disease (CVD) and cancer (14).

Table 1. Inflammatory response levels modified according to Finch, 2010 Biological level ROS oxidation of DNA, lipids and proteins; glycooxidation (AGE formation)

Cellular level activation of macrophages by endotoxins; oxidized proteins, lipids and AGE; autogenous inflammation from replicative cell senescence

Systemic level humoral elevation of CRP, IL-6 and cytokines; redox shift in glutathione; induction of fever by IL- 6 and TNFa; increased basal metabolic rate; lethargy and other sickness behaviors

Environmental infectious pathogens that cause systemic inflammation and focal lesions; ambient inflammogens from combustion of fossil fuels and tobacco

Abbreviations: ROS-reactive oxygen species; DNA-deoxyribonucleic acid; AGE- advanced glycation end products; CRP- $C$ reactive protein; IL-6 - interleukin 6; TNFa; tumor necrosis factor alpha

Inflammation-associated cellular-molecular damage is recognized as a major feature in aging (3). By-stander damage by reactive oxygen species (ROS) to neighboring cells and molecules is an important source of oxidative damage during aging that interacts with the endogenous damage from free radicals (1-3). The activation of macrophages and neutrophils increases secretion of ROS, which can cause oxidative by-stander damage to deoxyribonucleic acid (DNA) and proteins within a cell and neighboring cells and extracellular proteins (1). Immune activation in response to specific antigens can also have by-stander effects through secretion of interferon $\gamma(\operatorname{IFN} \gamma)$ and other cytokines that influence the differentiation of neighboring $\mathrm{T}$ cells (2). Thus, the oxidized molecules from by-stander damage are recognized by macrophages-through RAGE receptors (receptors for AGE /advanced glycation endproducts/)
$(15,16)$. These transmembrane receptors can stimulate further inflammatory reactions (1). RAGE has broad ligand binding and is a mediator of systemic oxidative stress and inflammatory responses (15-18). Additionally, blood glucose concentration is directly linked to inflammatory changes in many aspects of aging, by driving the formation of AGE, which in turn is directly linked to vascular disease (1). Microbial pathogens also activate RAGE (19).

Obesity, as a chronic low grade inflammatory process, can damaging effects on many organ systems $(20,21)$. Namely, the number of obese individuals worldwide has reached two billion, leading to an explosion of obesity-related health problems associated with increased morbidity and mortality $(20,22,23)$. Many of the comorbid conditions are related to metabolic syndrome (MS), characterized by a visceral (abdominal) obesity, dyslipidemia, glucose intolerance and high arterial blood pressure (24-26). The prevalence of the MS is age-dependent. Advancing age affects all levels of pathogenic components of the MS (27-29). Age-related alterations contributing to the increased prevalence of the MS in elderly subjects is presented in Table 2 (27). Each component of MS is independent cause of cardiovascular events, such as stroke, cardiomyopathy, coronary artery disease (CAD), myocardial infarction, cardiac insufficiency and sudden cardiac death (30). CVD, including heart disease, vascular disease and atherosclerosis, are the most critical global health threat, contributing to more than one-third of the global morbidity (21). CVD is the highest cause of death globally, too (31). In most cases, clinical manifestations of CVD result from atherosclerosis, which was identified as a lipid-storage disease. At the present time, CVD is recognized as a chronic inflammatory condition of the vessel wall, that results from the transendothelial passage (transcytosis) of cholesterol-rich atherogenic Apo-B lipoproteins from the plasma into the intima (21). It is likely that inflammation induced by obesity accelerates the atherosclerosis

Table 2. Age-related alterations contributing to the increased prevalence of the MS in elderly subjects

$\begin{array}{lc}\text { Alterations } & \text { Contribution } \\ \text { Body composition } & / \\ \text { Increased visceral fat } & \text { proinflammatory status } \\ \text { Increased fat in muscle and liver } & \text { IR } \\ \text { Decreased lean body mass } & \text { IR } \\ \text { Immunosenescence } & / \\ \text { Low grade inflammation } & \text { IR } \\ \text { Activation of the innate immune system } & \text { IR } \\ \text { Receptor signaling alterations } & / \\ \text { Insulin receptor } & \text { IR } \\ \text { Toll like receptors } & \text { proinflammatory status } \\ & / \\ \text { Stress } & \text { IR and proinflammato- } \\ \text { Increased oxidative stress } & \text { ry status } \\ \text { Increased ER stress } & \text { IR } \\ \text { Increased adrenal hormones (cortisol, etc.) } & \text { IR }\end{array}$

Abbreviations: MS-metabolic syndrome; IR-insulin resistance; ER-endoplasmic reticulum 
$(5,21,24,30,31)$. In particular, obesity as the most common nutritional disorder in industrialized countries, is closely related to impaired endothelial function, a wellknown marker of preatherosclerotic disease $(21,32)$. Having in mind the growing population of overweight and obese people worldwide, along with an increasingly aging population, understanding the pathophysiology of obesity on cardiovascular system is essential. The mechanisms linking obesity-related vascular disorders and low grade inflammation in aging process are the focus of this paper.

\section{INFLAMMATORY RESPONSE OF THE VESSEL WALL IN OBESITY}

The term endothelial dysfunction refers to a maladapted endothelial phenotype characterized by reduced nitric oxide (NO) bioavailability, increased oxidative stress, elevated expression of proinflammatory and prothrombotic factors, and abnormal vasoreactivity to endothelial-dependent stressor (32). Experimental and clinical data support a link between systemic inflammation and endothelial dysfunction $(21,25,30,32,33)$. Moreover, endothelial dysfunction has increasingly been recognized to play an important role in a number of conditions associated with a high prevalence of atherosclerotic $\operatorname{CVD}(21,25,30)$. It is regarded as an early stage of atherosclerosis, which is a chronic inflammatory disease (21).

\section{Foam cells}

Experimental atherosclerosis induced by high-cholesterol diet is often associated with pulmonary emphysema (34-37), increased levels of triglycerides (TG) and high concentrations of free fatty acids (FFA) in the blood and lung tissue (34). In rabbits, after a month of hypercholesterolemic diet, aortic lesions become microscopically visible. They are characterized by the accumulation of foam cells in the internal elastic membrane, while the endothelial surface is intact. Foam cells are a characteristic feature in the tissue response associated with bronchial obstruction (34-37).

In an experimental model of atherosclerosis induced by a high-cholesterol diet, monocytes are first cell adjacent to the endothelium. Then they migrate into the subendothelial space, swallow the oxidized cholesterol, and transform it into foam cells (33). Hypercholesterolemia associated with elevated levels of atherogenic lipoproteins (low density lipoprotein /LDL/ and very low density lipoprotein /VLDL/) in the blood, leads to chronic presence of LDL in the arterial wall (21). This condition enhances fatty streaks formation, because lipid migration into the subendothelium is greater than its removal from the arterial wall. It is known that local cytokine secretion and modification of native lipoprotein particles, that are internalized by vascular macrophages via the scavenger receptors class A (SRA) on the surfaces of these cells, lead to the formation of foam cells. Thus, exacerbation of local inflammatory process in the vascular tissue, due to generation of ROS, resulting in further lipoprotein modification and cytokine production (33). It has been shown that mononuclear phagocytic blood cells take part in the phagocytosis of native particles to a lesser extent, and of modified LDL particles to a greater extent after their binding to the SRA. However, these particles may directly migrate into the subendothelium, being subject to phagocytosis, whereas SRA play an important role in the process. These receptors, which mediate the delivery and degradation of modified LDL particles, do not operate on the principle of negative feedback, so even when a large amount of lipid particles is accumulated in the cell, the intake continues, which leads to the formation of foam cells (38). In a state of continuous inflammation, the concentration of LDL particles in blood increases and through the process of passive diffusion they penetrate the arterial intima, where they are trapped by glycosaminoglycans, whereas ROS are being affected as well. LDL particles become highly sensitive to different stimuli, and may be modified by oxidation, glycosylation, or by incorporation into immune complexes. In addition, LDL particles interact with proteoglycans (biglycan and decorin) and form aggregates, with a catalytic activity of sphingomyelinase, cathepsin D, cathepsin F and lysosomal acid lipase (39).

The ability of oxidized LDL molecules (oxLDL) to induce accumulation of cholesterol in macrophages was their first described proatherogenic property. Other proatherogenic effects of oxLDL particles, referring to endothelial cells, include expression of growth factors affecting smooth muscle cells, generation of superoxide anion $\left(\mathrm{O}_{2}\right)$, and endothelial cells apoptosis (38). The human endothelial receptor that mediates uptake of oxLDL belongs to $\mathrm{C}$ type lecitin family and is referred to as LOX-1 (lecitin-like oxLDL receptor-1) (33). Foam cell formation is also induced by receptors involved in oxLDL uptake (CD34, macrosialin/ CD68/) and HDL receptor, which is referred to as SB-1 (33).

It is believed that macrophage-colony stimulating factor (M-CSF), interleukin-3 (IL-3) and granulocyte monocyte colony stimulating factor (GM-CSF) play a key role in the process of foam cell formation (40).

Apart from macrophages, foam cell formation is also promoted by vascular smooth muscle cells with properties of lipophages (41).

\section{Preatherosclerotic disease}

Numerous animal studies have shown that activation of endothelial cells and expression of specific molecules, responsible for adhesion, migration and accumulation of monocytes and T-lymphocytes, play a crucial role in atherosclerosis (33). 
There is evidence that a high cholesterol diet is associated with fast focal expression of vascular cell adhesion molecule-1 (VCAM-1) at predilection sites. In addition, lysophosphatidylcholine, a component of modified lipoprotein, activates VCAM-1 gene transcription in endothelial cells. Lipoprotein(a), however, induces a dose-dependent expression of intercellular adhesion molecule-1 (ICAM-1) on endothelial cells, but it does not affect the expression of VCAM-1 and E-selectin. Furthermore, native LDL molecules, binding to the LDL receptors, increase the concentrations of VCAM-1 and E-selectin in human vascular endothelial cells (41). On the other hand, expression of these molecules is induced and enhanced by tumor necrosis factor alpha (TNFa) and interleukin-1 beta (IL-1 $\beta$ ), which originate either from the circulating blood or the vascular wall. These molecules, which are part of the existing local or systemic inflammatory reaction, apart from stimulating the expression of adhesion molecules, lead to changes in procoagulant and fibrinolytic endothelial cells, and the surface of the endothelium becomes thrombogenic. Modifying the properties of endothelial morphology, these cytokines affect the production of $\mathrm{NO}$ and prostacyclin, inducing endothelium to synthesize other cytokines, which enhances their proinflammatory activity. IL-1 and TNFa, endothelial cell activators, induce synthesis of specific membrane glycoproteins, redistributing the cytoskeleton of endothelial cells and increasing the synthesis of platelet-activating factor (PAF). PAF is a phospholipid with potential proinflammatory and thrombogenic properties. Its specific significance in atherosclerosis is indicated by the fact that components similar to this phospholipid are present in oxLDL, and that blockade of PAF receptors completely blocks effects of oxLDL molecules on peripheral mononuclear cells, in regard to the secretion of interferon- $\gamma$ (IFN- $\gamma$ ) and partly to the secretion of TNFa. IL-1 and TNFa also stimulate endothelial cells to produce interleukin-8 (IL-8) that strongly attracts and activates leukocytes. Migration of leukocytes through the morphologically intact endothelium involves direct migration as a response to other cytokines, so-called chemokines. In the early phase of atherogenesis these are monocyte chemotactic protein-1 (MCP-1), localized in atherosclerotic lesions, IL-8, interleukin-16 (IL-16), and C5a-receptor fragment peptide, released in hypercholesterolemia $(38,40)$.

Inflammatory response has been confirmed to affect accumulation of lipoproteins in the arterial wall. Inflammatory mediators (TNFa, IL-1 and M-CSF) increase the binding of LDL to the endothelium and smooth muscle cells (33). After binding to SRA in vitro, modified LDL particles initiate a series of intracellular events, among which activation of urokinase and inflammatory cytokines plays an important role. In this way, due to the presence of lipids, a vicious cycle of inflammation is maintained in the arteries, as well as modification of lipoproteins and continuous inflammation (38, 41).
Thus, LDL molecules enhance the expression of SRA on macrophages and in synergy with inflammation facilitate formation of foam cells (41). Also, it should be noted that a large number of activated macrophages is undergoing apoptosis, after which they release lipid content into the matrix and form the lipid nucleus of atheromas (40).

Various studies demonstrate the involvement of immune factors in the etiology of atherosclerosis $(21,25$, $33,38,40)$. Apart from antigens responsible for immune responses leading to atherosclerosis, special attention is paid to vascular wall antigens. For example, aging causes loss of elastin natural properties, and thus it becomes susceptible to deposition of calcium and elastolysis. Enhanced decomposition of insoluble elastin in the vascular wall leads to the appearance of peptides in the blood stream, whereas anti-elastin antibodies are created in response to them (40). Rabbits with experimental atherosclerosis exhibit a progressive titer increase of these antibodies, as well as abnormal accumulation of microfibrils in the elastic tissue, which is closely associated with excessive elastolysis of preformed or newly formed elastic fibers during elastic tissue remodeling. Enhanced synthesis of microfibrils may occur in response to elastolysis as a reparative phenomenon, but also represents a response of the blood vessel wall to elastolysis (33). In addition, atherosclerotic lesions accumulate "senescent" cells defined by markers of replicative senescence (senescence-associated b-galactosidase) and telomere shortening. Then, replicative senescence induced inflammatory gene expression (1).

Histochemical methods showed an increased non-specific esterase activity of macrophages in the arterial walls during atherogenesis induced by hypercholesterolemic diet. It has also been observed that the amount of esterase is directly proportional to the degree of saturation of the intima with lipoproteins and other macromolecules (33). Besides, it has been established that different local stimuli (immune complexes, antigens, lymphokines, bacterial components, etc.) may trigger the release of hydrolytic lysosomal enzymes into the extracellular space with autodestructive consequences. In addition, the degree of esterase activity in mononuclear cells correlates with cell viability and mitotic capacity (42).

In the vessels of obese patients, a shift of the normal prevalence of NO-mediated vasodilator tone towards an enhanced endothelin-1 (ET-1) -mediated vasoconstriction has, in fact, been observed (32). The presence of endothelial dysfunction in patients with obesity and insulin resistance (IR) was first reported by Steinberg et al, over a decade ago. These authors demonstrated a blunted increase of leg blood flow in response to graded intraarterial doses of the muscarinic receptor agonist methacholine in patients with elevated BMI or type 2 diabetes compared to lean controls (43). These observations have 
been followed by exploration of the cellular and molecular action of insulin on the vasculature. Quon and colleagues 2007 demonstrated that the molecular signaling pathways mediating insulin stimulation of $\mathrm{NO}$ production in endothelial cells are similar to signaling pathways mediating insulin activation of glucose transport in classical target tissues (i.e. the phosphatidylinositol 3-kinase /PI3K/ pathway) (44). Also, it has been shown mild elevation of fasting blood glucose after age 40 (1). The progressive glycemia of normal aging is emerging as a canonical feature of aging paralleling the increase in systolic blood pressure and atherosclerosis. It seems potentially important that mortality risk at later ages becomes increasingly sensitive to blood glucose (45).

\section{ADIPOSE TISSUE AS AN ENDOCRINE ORGAN}

For many years, adipose tissue was regarded merely as a heat insulator and a store of excess FFA that could be released when needed (46). During recent years, in fact, adipose tissue has been acknowledged as a major endocrine and paracrine organ, that produces adipokines, hormones and cytokines $(32,46,47)$. These molecules contribute to the modulation of insulin activity and resistance, and metabolism of fat and glucose indirectly determining atheroslerosis (32).

Adipose tissue contains various cells, such as adipocytes, preadipocytes, vascular cells, endotheliocytes, lymphocytes and macrophages expressing CD14 receptors (47). In obesity, the increased production of inflammation mediators in the adipose tissue, liver, pancreas and skeletal muscles causes subclinical metabolic inflammation $(32,47)$. This inflammation affects the metabolic and secretory function of adipose tissue and plays a leading role in the development of obesity accompanying MS, diabetes mellitus and atheroslesrosis $(32,46,47)$. The main source of proinflammatory mediators in this process are CD14+ cells. Furthermore, metabolic inflammation also involved cell infiltration, fibrosis development, impaired microcirculation, enhanced adipokines and proinflammatory cytokines in the visceral adipose tissue and increase of non-specific inflammatory biomarkers (CRP, fibrinogen, etc.) and leukocytes in the blood (47).

Perivascular adipose tissue (PVAT) surrounds blood vessels in changing amounts and is produced from the vascular lamina adventitia in response to circulating factors and local stimuli (46). It can be considered as a paracrine organ that transduces metabolic signals from the adipose tissue to blood vessels (48). Thus, PVAT can play an active role in regulating vascular tone and releases adipocyte-derived vascular relaxation factors into blood vessels $(46,48)$. Excess calories and inactivity enlarge PVAT depots with potentially unfavorable consequences and an increase in PVAT is suggested to me- diate morphologic changes associated with an increse in vascular stiffness seen in obesity (46). In obesity, PVAT dysfunction triggers inflammation, oxidative stress, and hypoxic processes to promote vascular dysfunction (32).

PVAT secretes yet unidentified perivascular adipose tissue derived relaxing factor (PVADRF). In obesity, dysfunction and inflammation of adipose tissue result in impaired production of PVADRF (48). It has been shown a critical role of ROS from PVAT in the impairment of endothelium-dependent vasodilation in diet-induced obese mice $(32,48)$. Many adipokines with anticontractile properties, including leptin, adiponectin, angiotensin 1-7, hydrogen sulfide, visfatin and methyl palmitate have been proposed as potential candidates for PVADRF. However, none of them fully mimics the vascular effects of PVADRF and its precise identity remains to be elucidated (48).

Considering that PVAT contributes to vascular diseases, it is suggested that PVAT may be a novel target for treatment of atherosclerosis and restenosis after coronary intervention (48). Restenosis at sites of vascular injury following angioplasty is a phenomenon in which vascular smooth muscle cell (VSMC) phenotype switches to proliferation and migration as in the case in atherosclerosis (48). The local microenvironment, influenced by growth factors and inhibitors, is very important for the phenotypic conversion $(32,48)$. There is ample evidence that factors released from PVAT regulate VSMC proliferation and migration $(32,46,48)$. It is also suggested that epicardial adipose tissue may serve as a local source of proinflammatory cytokines involved in the development of CAD. It was found in patients that there is an independent relationship between increased epicardial adipose tissue and carotid intima-media thickness (IMT) (48).

\section{Adipokines and inflammation}

The adipocytes, preadipocytes and macrophages within adipose tissue secrete a variety of hormones known as adipokines $(46,49)$. The list of adipokines continues to grow to hundreds of factors $(32,48)$. Some of these adipokines like leptin play a role in homeostasis of body weight by controlling food intake (48). High leptin concentrations correlate with adverse cardiovascular outcomes in obese patients (32). Hyperleptinemia has been shown to be an independent risk factor for CAD and a strong predictor of acute myocardial infarction and stroke $(32,50)$. Besides, adipose tissues expresses enzymes involved in the angiotensin system (RAS) (renin, angiotensin-converting enzyme /ACE/), as well as the nonrenin-angiotensin system (NRAS) (cathepsin D, cathepsin G, tonin, chymase) (21).

More recently, it has become clear that many adipokines are mediators in the "adipo-cardiovascular axis", the cross talk between adipose tissues, the heart and the vasculature 
$(46,48,49)$. Related to CVD one can distinct "healthy" (of which adiponectin and omentin are best characterized) and "unhealthy" adipokines. Interestingly, the "healthy" adipokines are decreased in obesity while the "unhealthy" adipokines, such as TNFa, IL-6, plasminogen activator inhibitor-1 (PAI-1), adipocyte fatty acid binding protein (A-FABP), lipocalin 2, chemerin, leptin, visfatin, vaspin, resistin are upregulated in obesity-related vascular disorders (48). The most important adipokines and their effects on vascular function is shown in Table 3. It is now evident that many of these adipokines have the ability to influence other tissues, such as liver and muscle (46). These molecules secrete into the circulation and participate in regulation of a number of chronic diseases affecting insulin sensitivity, glucose and lipid metabolism, as well as cardiovascular homeostasis (49).

Under normal conditions, the adipocyte is a site of lipid synthesis, uptake and storage (46). Secreted adipokines function as either endocrine, paracrine or autocrine mediators $(32,46,49)$. Increases of adipocyte size can lead to deleterious alterations in insulin sensitivity caused by a decrease in adiponectin secretion, an increase in the release of FFA and the induction of inflammatory mediators $(46,49)$. Large adipocytes are more insulin-resistant and lipolytic, and release more inflammatory cytokines and less adiponectin. They are also more frequently found in individuals with obesity-related metabolic disorders (46). Enlargement of adipocytes is also associated with physical stress and increased ROS production ( 1 , 46). These stress factors induce production of inflammatory adipokines, such as IL-6 and serum amyloid A (SAA), that are released into the circulation and mediate the recruitment of activated monocytes into adipose tissue $(46,49)$. In obesity, under these conditions, adipose tissues, especially activated macrophages, produce proinflammatory adipokines, such as TNFa, leptin, IL-6, monocyte chemoattractant protein-1 (MCP-1), lipocalin-2, resistin, A-FABP, PAI-1, that further encourage vascular disease $(21,46,49)$. In these circumstances, production of adiponectin is markedly reduced (46-59) and inversely correlated with BMI and visceral fat (32). All of these changes have been shown to be key contributors to obesity-related vascular disease $(46,49)$.

Table 3. Effects of adipokines on vascular function

\begin{tabular}{|c|c|}
\hline Adipokine & Effects on vascular function \\
\hline Adipocyte fatty acid binding protein (A-FABP) & proinflammatory effect \\
\hline Adiponectin & $\begin{array}{l}\text { direct vasodilatory effect; } \uparrow \text { VSMC proliferation and migration; } \uparrow \text { vascular permeabili- } \\
\text { ty; } \uparrow \text { oxidative stress; insulin-sensitizing effect; anti-inflammatory and } \\
\text { anti-dyslipidemic activities }\end{array}$ \\
\hline Angiotensinogen & $\begin{array}{l}\text { vasoconstrictor; proinflammatory effect; } \\
\downarrow \text { NO bioavailability }\end{array}$ \\
\hline Apelin & proinflammatory effect \\
\hline Atrial natriuretic peptide (ANP) & blood volume control \\
\hline Chemerin & proinflammatory effect \\
\hline $\mathrm{C}$ reactive protein $(\mathrm{CRP})$ & proinflammatory effect; strong independent risk factor for endothelial dysfunction \\
\hline Endothelin-1 (ET-1) & vasoconstriction; VSMC proliferation; cell adhesion \\
\hline Free fatty acids (FFA) & $\downarrow$ endothelium-dependent vasodilation \\
\hline Ghrelin & vasodilation; $\uparrow \mathrm{NO}$ production \\
\hline Interleukin-1b (IL-1b) & proinflammatory effect \\
\hline Interleukin-6 (IL-6) & proinflammatory effect; strong independent predictor for future cardiovascular events \\
\hline Interleukin-8 (IL-8) & proinflammatory effect \\
\hline Leptin & $\begin{array}{l}\text { direct vasodilatory effect; } \uparrow \text { VSMC proliferation and migration; } \uparrow \text { vascular permeabil- } \\
\text { ity; } \uparrow \text { oxidative stress }\end{array}$ \\
\hline Lipocalin-2 & proinflammatory effect \\
\hline Monocyte chemoattractant protein-1 (MCP-1) & proinflammatory effect \\
\hline Nitric oxide (NO) & Vasodilation \\
\hline Omentin & vasoprotective effect \\
\hline $\begin{array}{l}\text { Perivascular adipose tissue derived relaxing fac- } \\
\text { tor (PVADRF) }\end{array}$ & anticontractile vascular properties \\
\hline Plasminogen activator inhibitor-1 (PAI-1) & $\uparrow$ VSMC proliferation \\
\hline Reactive oxygen species (ROS) & eNOS uncoupling; proinflammatory effect \\
\hline Resistin & $\begin{array}{l}\text { reduced eNOS expression; } \uparrow \text { endothelial cell activity; } \\
\uparrow \text { VSMC proliferation; } \uparrow \text { VSMC migration }\end{array}$ \\
\hline Retinol-binding protein 4 (RBP4) & proinflammatory effect \\
\hline Serum amyliod A (SAA) & proinflammatory effect \\
\hline Tumor necrosis factor a (TNFa) & $\begin{array}{l}\downarrow \text { endothelium-dependent vasodilation; } \\
\text { reduced eNOS expression; induces ET-1 and PAI-1; } \\
\text { oxidative stress }\end{array}$ \\
\hline Vaspin & proinflammatory effect \\
\hline Visfatin & proinflammatory effect \\
\hline
\end{tabular}


Scheme 1. Inflammation and obesity-related vascular disorders

Inflammation

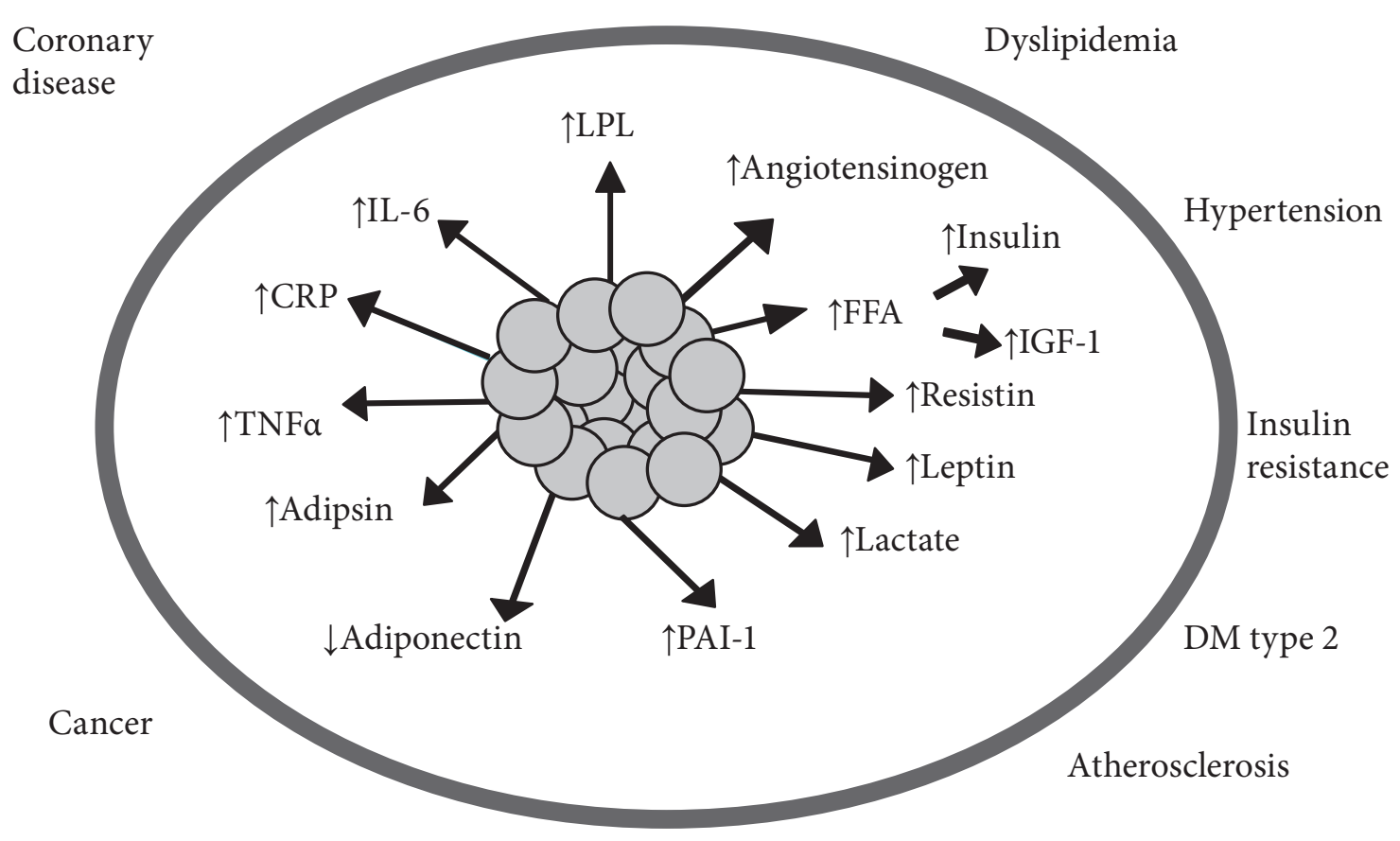

Thrombosis

Abbreviations: CRP- C reactive protein; DM - diabetes mellitus; IGF-1 - insulin like growth factor-1; IL-6 - interleukin-6; FFA-free fatty acid; LPL-lipoprotein lipase; PAI-1 - Plasminogen activator inhibitor-1; TNFa-Tumor necrosis factor a

As in obesity, also aging is associated with altered function, size and number of adipose cells, with altered distribution of adipose tissues in the body and with hypoxia in adipose tissue, especially in the visceral depots (48).

\section{Oxidative stress and inflammation}

Endothelial dysfunction in obesity is characterised by increased generation of $\operatorname{ROS}(32,50)$. This is contributed by vascular cells and inflamed hypertrophied adipocytes as a result of endoplasmic reticulum (ER) stress and mitochondrial dysfunction $(8,21,50)$. Enzymes of mitochondrial electron transport chain, xanthine oxidase, cyclooxygenases, lipoxygenases, myeloperoxidases, cytochrome P450 monooxygenase, heme oxygenases, peroxidases and $\mathrm{NAD}(\mathrm{P}) \mathrm{H}$ oxidases contribute to endothelial dysfunction (50). Uncoupling of endothelial nitric oxide synthase (eNOS) is a major contributor to ROS production $(32,50)$. This results in decreased NO bioavailability, increased superoxide anion $\left(\mathrm{O}_{2}\right)$ production and formation of peroxynitrite (ONOO-), a key mediator of lipid peroxidation and foam cell formation in atherosclerotic lesions (50). Additionally, ROS accumulation results in activation of signalling cascades that regulate transcription factors, including nuclear factor kappa beta (NF-kb) adhesion molecules, chemotactic factors, antioxidant enzymes, and vasoactive substances promoting adhesion and migration of circulating monocytes initiating atherosclerotic lesions (39, 50). Dysregulated adipokine production leading to in- creased ROS generation forms a major feedback loop in initiation, maintenance and progression of endothelial dysfunction (50).

\section{Insulin resistance and inflammation}

Inflammation and IR in obese individuals are mutually amplifying processes that increase the risk of cardiovascular morbidity and mortality (32). The accumulated evidence indicates that IR is a key pathogenic factor for MS (59). Namely, it is generally believed that elevated blood pressure, dyslipidemia and impaired glucose tolerance are caused by IR $(24,25,27,59)$.

IR is often associated with increased adipose tissue mass (59). Proinflammatory cytokines produced by adipocytes contribute, at least in part, to IR by interfering with normal insulin receptor intracellular signaling (32). On the other hand, obesity-related IR is well-known to promote inflammation through diverse mechanisms including oxidative stress, stimulation of proinflammatory adipokines, AGEs, and FFAs (32). Dysfunctional adipose tissue with low grade, chronic and systemic inflammation links the metabolic and vascular pathogenesis including dyslipidemia, low grade inflammation and IR and is a hallmark of disorders such as type 2 diabetes and CVD (46). However, lifestyle factors and, to a lesser degree, genetic factors, are also involved $(32,46)$. 
Lipid accumulation in liver and muscle is an early hallmark of type 2 diabetes $(11,12,46)$. In the pancreas, lipid accumulation has been shown to precede suppressed glucose-mediated insulin production (46). In the lipid-overloaded heart, metabolic dysregulation may induce IR resulting in impaired glucose oxidation, and, ultimately, heart failure $(6,46)$.

Large adipocytes are more frequently found in subjects with impaired glucose tolerance and type 2 diabetes than those with a similar degree of adiposity but with normal glucose tolerance, and impaired adipocyte differentiation appears to be one of the most important factors in the progression of type 2 diabetes (46). Insulin has several functions, including the transport of nutrients into cells, the regulation of gene expression and energy homeostasis. It acts on a number of target tissues and through many different intracellular signaling cascades $(8,10,14)$. Elevated levels of intracellular FFAs can blunt the response to insulin and subsequent metabolic effects $(32,46)$.

Insulin receptor substrate-1 (IRS-1) is a key molecule in the insulin signaling pathway and failure to activate IRS-1 leads to systemic IR (46). Inhibitory phosphorylation of IRS-1 can be induced through inflammatory agents, such as TNFa and IL-6, but also through activation of receptors, such as the Toll-like receptors (TLR), or intracellular molecules such as lipids and ROS (27, 46). Activation of the TNFa and IL- 6 receptors induces activation of important activators of inflammation i.e. IkB kinase (IKKb) and Janus kinase (JNK) (46). JNK is also activated by FFAs and ER stress, factors that are associated with obesity-induced activity $(25,27,46)$. IKKb does not phosphorylate IRS-1, but causes IR through activation of NFkB (25). Supressor of cytokine signalling (SOCS) inhibits insulin actions on IRS-1, either by interfering with the tyrosine phosphorylation, or by targeting IRS-1 for proteosomal degradation (46).

The consequences of decreased insulin production as a result of ectopic lipid accumulation in the pancreas combined with a diminished activation of the insulin receptor in adipocytes results in an impairment of insulin-stimulated glucose transport, a reduced anti-lipolytic effect, an increase in the amount of FFA released, impaired preadipocyte differentiation and a decrease in lipoprotein lipase (LPL) production and activity (46). These effects will lead to the development of IR, type 2 diabetes and CVD $(46,51)$.

An increase in the amount of AGEs also contribute to the development of vascular complications in diabetes, inducing endothelial dysfunction $(16,17,51)$. Several mechanisms by which this heterogeneous group of compounds formed by nonenzymatic glycation of proteins and lipids lead to endothelial dysfunction have been proposed, such as the accumulation of AGEs in the extracellular matrix, the binding of circulating AGEs to the endothelial surface receptor for AGEs (RAGE) with subsequent generation of ROS, the cytokine release and the expression of cell adhesion molecules (51).

\section{NAFLD AND ADIPOSE TISSUE INFLAMMATION}

The liver is an organ that is vulnerable to ectopic fat accumulation (60). Currently, the incidence of nonalcoholic fatty liver disease (NAFLD) mirrors the prevalence of obesity and MS, and NAFLD is now one of the most common causes of chronic liver disease worldwide (61). Notably, NAFLD is not a single disease entity, but describes a spectrum of liver conditions. The disorder ranges from simple fatty liver (steatosis) to more severe steatosis coupled with marked inflammation termed nonalcoholic statohepatitis (NASH), which can progres to fibrosis, and subsequently to liver cirrhosis, liver failure and hepatocellular carcinoma (62).

NAFLD is now considered as a hepatic manifestation of MS (60-62). In support of this, recent studies have shown that severe NAFLD is linked to an incressed risk of CVD $(25,27,60,62)$. These studies suggest that NAFLD may be actively involved in the pathogenesis of CVD, potentially through the increased release of proatherogenic factors from the liver (CRP, fibrinogen, PAI-1 and other inflammatory cytokines). Alternatively, NAFLD is involved in in whole-body IR and dyslipidemia. For example, once significant hepatic steatosis occurs, the liver becomes insulin resistant and overproduces both glucose and VLDL, which in turn leads to hyperglycemia, hypertriglyceridemia and low concentration of high density lipoproteins (HDL) (62). However, whether IR precedes ectopic fat deposition or whether fat accumulation is a consequence of IR remains an unanswered question (64).

As previously described, ectopic fat is an important source of inflammatory mediators, cytokines and adipokines. It is possible that adipose tissue inflammation plays a role in the pathogenesis of NAFLD (63). Indeed, analysis of adipose tissue from subjects with severe liver steatosis has suggested that inflamed adipose tissue characterises people with a high liver fat content (65). In mice, the overexpression of an inflammatory marker in adipose tissue, macrophage chemotactic protein-1 (MCP-1), is thought to lead to macrophage infiltration and hepatic steatosis (66). However, it is also possible that hepatic inflammation may precede that of other insulin-sensitive tissues, as the hepatic activation of $\mathrm{NFkB}$ via overexpression of IKKb can induce IR in the liver and muscle in addition to an increase in signs of systemic inflammation (IL-6) (63). In response to these findings, one can draw similarities between hepatic fat and more traditional sites of proinflammatory adiposopathic ectopic fat, predominantly influenced by a high 
fat diet (67). Therefore, liver with NAFLD may play an even larger role in the whole body inflammatory state, because the liver itself is in an advanced state of inflammation $(68,69)$.

\section{INFLAMMATION, OBESITY-RELATED VASCULAR DYSFUNCTIONS AND AGING PROCESS}

Cardiovascular events, diabetes mellitus resulting from the MS as well as cancer are the common cause od death of aging humans $(27,28)$. Why is it so? As it is previously described, advancing age affects all levels of patgogenic components of the MS (27-29). With aging we assist to a change in the body composition characterised by the redistribution of the body composition in favour of the adipose tissue. The increase in the adipose tissue is especially marked centrally, as well as in muscle and liver. In the mean time the lean body mass is also decreasing, which favours the IR in the muscle (27). In addition, the aging process is associated with a low grade inflammation due to the deregulated functioning of the innate immune system over adaptive immune system resulting from chronic antigenic stimulation of all types including infections and nutrition $(1,27,70,71)$. This results in the increase in circulating levels of FFA and proinflammatory cytokines enforcing the already existing IR (27). Thus, the better understanding of the interplay between the metabolic response and immunosenescence could lead to important understanding of both processed during aging.

Aging is also associated with a change in the hormones implicated in metabolism including insulin like growth factor-1 (IGF-1), the growth hormone and insulin (1,27, 72-74). IGF-1 recently has become a major determinant in nematode and fly longevity (27). Evidence suggests that disruption in IGF-1 signalling uniformly extends lifespan in animal species $(1,27)$. Of course, no direct conclusion can be drawn for human longevity (27). However, the decrease, as well as the increase IGF-1 levels were related to various diseases $(27,74)$. Insulin sensitivity declines with age and is associated with increased morbidity and mortality due to atherosclerosis, CVD, obesity and diabetes, all related to dysregulation of the aging immune system (immunosenescence) (27, 31,77 ), as well as to dementia (20). Studies in healthy centenarians show enhanced insulin sensitivity demonstrating an important role of healthy insulin signalling for long life (27). How exactly it could happen is still to be discovered. Probably the newly discovered SIRT gene family, actually seven members could play an important role $(1,27)$. Nevertheless, vigorous prevention and/or treatment of IR and components of the MS could have important implications for human longevity (27).

\section{Caloric restriction and inflammation}

Many observational and experimental studies have considered that caloric restriction may be associated with life prolongation, possibly through an improvement of the cell redox balance (78). Also, increase degeneration of mitochondrial ROS and oxidative damage seem to be differently induced by nutritional perturbation and state $(31,78,79)$. In animal experiments, hypocaloric diet and antioxidant supplementation were associated with improvement of some tissue functions and redox states that, conversely, were oxidatively depressed in aged control animals (78). A key event associated with diet restriction is the activation of a class of genes belonging to the SIRT family, which is involved in cell maturation and apoptotic processes $(1,27,78)$. Recently, it is shown that resveratrol, an antioxidant poliphenol of red wine, was able to activate these genes by mimicking the effect of diet restriction $(31,78)$. Successively, it is reported that high dose of resveratrol was able to contrast the development of CVD and diabetes in mice fed with hypercaloric diet, suggesting a role for oxidative stress in systemic inflammation and damages in conditions stimulating the MS $(31,78)$.

Diet has major systemic influences on inflammation through the levels of energy intake, energy storage in fat depots, and ingested AGEs produced during cooking (1). As a general principle, innate immune responses are regulated by the energy available $(1,3,70)$. Caloric restriction, besides limiting the febrile response, attenuates other acute phase responses (1). A systemic mechanism in caloric restriction may be elevation of corticosteroids, which is a broad gluconeogenic homeostatic response to partial starvation to maintain sufficient levels of blood glucose $(1,2)$. Lowering of blood glucose by caloric restriction attenuated production of AGEs, that further kindling inflammatory process (1). Besides, AGEs can act directly on pancreatic cells to impair insulin secretion through induction of iNOS (1). The oxidative load also is diminished by caloric restriction in most tissues $(1,27,31,67,78,80-82)$.

Gene expression profiling studies consistently show that caloric restriction attenuates the increased expression of cytokine and complement factor genes during aging in brain, heart, and liver $(1,83,84)$. Caloric restriction also attenuates atherosclerosis, cancer and Alzheimer' disease in rodent models $(1,27,78)$. In moderately obese patients, diet restriction lowered blood CRP and IL-6, with correspondingly lower incidence of cardiovascular events (1).

\section{CONCLUSION}

The pathogenesis of obesity-related vascular disorders has not been fully elucidated. The fundamental role of inflammation in aging process is now widely recognized, 
particularly for atherosclerotic disease which begins before birth. The strong age trends for elevated blood glucose and glycated proteins during starting midlife is hypothesized to be a fundamental driver of vascular disease and the acceleration of risk for cerebrovascular events. Obesity and MS are important risk factors for metabolic and CVD. Despite a well-known genetic component, this risk appears to originate from several abnormalities in adipose tissue function associated with a chronic inflammatory state. These conditions disrupt vascular homeostasis by causing an imbalance between the NO pathway and the ET-1 system, with impaired insulin-stimulated endothelium-dependent vasodilation.
Many research efforts are still required to unravel the complex relation between adipose tissue and CVD and the potential role of adipokines as biomarkers. A hope remains that future research on the role of these biological active molecules in the pathogenesis of obesity-related vascular disfunctions will shed light on yet unknown potential therapeutic modalities.

\section{Acknowledgements}

This work was supported by the Ministry of Education, Science and Technological Development of Republic of Serbia, Grant No. 175015.

\section{REFERENCES}

1. Finch CE. Inflammation in aging processes: an integrative and ecological perspective. In: Masoro E, Austad S, editors. Handbook of the biology of aging. San Diego:Academic Press; 2010. p. 1-45.

2. Finch CE. Evolution in health and medicine Sackler colloquium: Evolution of the human lifespan and diseases of aging: roles of infection, inflammation, and nutrition. Proc Natl Acad Sci U S A 2010;107:171824.

3. Finch CE. The biology of human longevity: inflammation, nutrition, and aging in the evolution of lifespans. $1^{\text {st }}$ edition. San Diego: Academic Press; 2007.

4. Mathieu P, Battista D, Depino A, et al. The more you have, the less you get: the functional role of inflammation on neuronal differentiation of endogenous and transplanted neural stem cells in the adult brain. J Neurochem 2010;112:1368-85.

5. Abarbanell AM, Coffey AC, Fehrenbacher JW, et al. Proinflammatory cytokine effects on mesenchymal stem cell therapy for the ischemic heart. Ann Thorac Surg 2009;88:1036-43.

6. Herrmann JL, Markel TA, Abarbanell AM, et al. Proinflammatory stem cell signaling in cardiac ischemia. Antioxid Redox Signal 2009;11:1883-96.

7. Korner J, Woods SC, Woodworth KA. Regulation of energy homeostasis and health consequences in obesity. Am J Med 2009;122:S12-8.

8. Lee DE, Kehlenbrink S, Lee H, et al. Getting the message across: mechanisms of physiological cross talk by adipose tissue. Am J Physiol Endocrinol Metab 2009;296:E1210-29.

9. Redinger RN. Fat storage and the biology of energy expenditure. Trans Res 2009;154:52-60.

10. Khaodhiar L, Ling PR, Blackburn GL, et al. Serum levels of interleukin- 6 and C-reactive protein correlate with body mass index across the broad range of obesity. JPEN J Parenter Enteral Nutr 2004;28:410-5.

11. Maury E, Brichard SM. Adipokine dysregulation, adipose tissue in flammation and metabolic syndrome. Mol Cell Endocrinol 2010;314:116.

12. Fontana L, Eagon JC, Trujillo ME, et al. Visceral fat adipokine secretion is associated with systemic inflammation in obese humans. Diabetes 2007;56:1010-3.

13. Minamino T, Orimo M, Shimizu I, et al. A crucial role for adipose tissue p53 in the regulation of insulin resistance. Nat Med 2009;15:1082-7.

14. Hevener AL, Febbraio MA; Stock Conference Working Group. The 2009 stock conference report: inflammation, obesity and metabolic disease. Obes Rev 2010;11:635-44.

15. Cai W, He JC, Zhu L, et al. AGE-receptor-1 counteracts cellular oxidant stress induced by AGEs via negative regulation of p66shc-dependent FKHRL1 phosphorylation. Am J Physiol Cell Physiol 2008;294:C14552.

16. Lin L, Park S, Lakatta EG. RAGE signaling in inflammation and arterial aging. Front Biosci (Landmark Ed) 2009;14:1403-13.

17. Herold $\mathrm{K}$, Moser B, Chen $\mathrm{Y}$, et al. Receptor for advanced glycation end products (RAGE) in a dash to the rescue: inflammatory signals gone awry in the primal response to stress. J Leukoc Biol 2007;82:204-12.
18. Gao L, Mann GE. Vascular NAD(P)H oxidase activation in diabetes: a double-edged sword in redox signalling. Cardiovasc Res 2009;82:9-20.

19. Chou MY, Hartvigsen K, Hansen LF, et al. Oxidation-specific epitopes are important targets of innate immunity. J Intern Med 2008;263:47988

20. Nguyen JC, Killcross AS, Jenkins TA. Obesity and cognitive decline: role of inflammation and vascular changes. Front Neurosci 2014;8:375.

21. Wang Z, Nakayama T. Inflammation, a link between obesity and cardiovascular disease. Mediators Inflamm 2010;2010:535918.

22. Li Z, Bowerman S, Heber D. Health ramifications of the obesity epidemic. Surg Clin North Am 2005;85:681-701.

23. Olshansky SJ. Projecting the future of U.S. health and longevity. Health Aff (Millwood). 2005;24:W5R86-9.

24. Grundy SM. Obesity, metabolic syndrome, and cardiovascular disease. J Clin Endocrinol Metab 2004;89:2595-600.

25. Haslam DW, James WP. Obesity. Lancet 2005;366:1197-209.

26. Pignone M, Salazar R. Disease prevention and health promotion. In: McPhee SJ, Papadakis MA, editors. Current medical diagnosis and treatment. New York:Mc Graw Hill; 2011. p. 1-21.

27. Fulop T, Tessier D, Carpentier A. The metabolic syndrome. Pathol Biol (Paris) 2006;54:375-86.

28. Bechtold M, Palmer J, Valtos J, et al. Metabolic syndrome in the elderly. Curr Diab Rep 2006;6:64-71.

29. Morley JE. The metabolic syndrome and aging. J Gerontol A Biol Sci Med Sci 2004;59:139-42

30. Caglayan E, Blaschke F, Takata Y, et al. Metabolic syndrome-interdependence of the cardiovascular and metabolic pathways. Curr Opin Pharmacol 2005;5:135-42.

31. Mohamed S. Functional foods against metabolic syndrome (obesity, diabetes, hypertension and dyslipidemia) and cardiovascular disease. Trend Food Sci Technol 2014;35:114-128.

32. Iantorno M, Campia U, Di Daniele $\mathrm{N}$, et al. Obesity, inflammation and endothelial dysfunction. J Biol Regul Homeost Agents 2014;28:169-76.

33. Vučević D, Radosavljević T, Djordjević D, et al. The relationship between atherosclerosis and pulmonary emphysema. Med Pregl 2014;67:231-8

34. Vučević D, Milovanović I, Mladenović I, et al. The effect of tocopherol on serum lipid profile in pulmonary emphysema induced by hyperholesterolemic diet. Acta Vet 2007;57:303-20.

35. Vučević D, Pešić BČ, Djarmati D, et al. Effect of tocopherol on experimental emphysema in rabbits. Period Biolog 2004;106:411-16.

36. Vučević D, Pešić BČ, Djarmati D, et al. The effect of tocopherol on serum iron content in experimental atherosclerosis. Acta Vet 2005;55:131-45.

37. Vučević D, Radosavljević T, Mladenović D, et al. Iron as an agent of oxidative injury in experimental atherosclerosis. Acta Vet 2011;61:631-41.

38. Frostegárd J. Immunity, atherosclerosis and cardiovascular disease. BMC Med 2013;11:117-129.

39. Valko M, Leibfritz D, Moncol J, et al. Free radicals and antioxidants in normal physiological functions and human disease. Int J Biochem Cell Biol 2007;39:44-84 
40. Frostegárd J. Immune mechanisms in atherosclerosis, especially in diabetes type 2. Front Endocrinol (Lausanne) 2013;4:162-172.

41. Song Z, Jin R, Yu S, et al. Crucial role of CD40 signaling in vascular wall cells in neointimal formation and vascular remodeling after vascular interventions.Arterioscler Thromb Vasc Biol 2012;32:50-64.

42. Lahoute C, Herbin O, Mallat Z, et al. Adaptive immunity in atherosclerosis: mechanisms and future therapeutic targets. Nat Rev Cardiol 2011;8:348-58.

43. Steinberg HO, Chaker $\mathrm{H}$, Leaming $\mathrm{R}$, et al. Obesity/insulin resistance is associated with endothelial dysfunction. Implications for the syndrome of insulin resistance. J Clin Invest 1996;97:2601-10.

44. Muniyappa R, Montagnani M, Koh KK, et al. Cardiovascular actions of insulin. Endocr Rev 2007;28:463-91.

45. Yashin AI, Ukraintseva SV, Arbeev KG, et al. Maintaining physiological state for exceptional survival: What is the normal level of blood glucose and does it change with age? Mech Ageing Dev 2009;130:611-8.

46. Gustafson B.Adipose tissue, inflammation and atherosclerosis. J Atheroscler Thromb 2010;17:332-41.

47. Litvinova L, Atochin D, Vasilenko M, et al. Role of adiponectin and proinflammatory gene expression in adipose tissue chronic inflammation in women with metabolic syndrome. Diabetol Metab Syndr 2014;6:137 doi:10.1186/1758-5996-6-137

48. Van de Voorde J, Pauwels B, Boydens C, et al. Adipocytokines in relation to cardiovascular disease. Metabolism 2013;62:1513-21.

49. Ebrahimi-Mamaeghani M, Mohammadi S, Arefhosseini SR, et al. Adiponectin as a potential biomarker of vascular disease. Vasc Health Risk Manag 2015;11:55-70.

50. Adya R, Tan BK, Randeva HS. Differential effects of leptin and adiponectin in endothelial angiogenesis. J Diabetes Res 2015;2015:648239.

51. Del Turco S, Navarra T, Gastaldelli A, et al. Protective role of adiponectin on endothelial dysfunction induced by AGEs: a clinical and experimental approach. Microvasc Res 2011;82:73-6.

52. Bachmayer C, Kemmer A, Ehrmann N, et al. Adipokines and endothelial dysfunction in obesity $\mathrm{WHO}^{\circ} \mathrm{III}$. Microvasc Res 2013;89:129-33.

53. Kizer JR. Adiponectin, cardiovascular disease, and mortality: parsing the dual prognostic implications of a complex adipokine. Metabolism 2014;63:1079-83.

54. Nigro E, Scudiero O, Monaco ML, et al. New insight into adiponectin role in obesity and obesity-related diseases. Biomed Res Int 2014;2014:658913.

55. Chang X, Jiao Y, Lu J, et al. Adiponectin and visfatin may serve as diagnosis markers for metabolic syndrome in Uygur population. Int J Clin Exp Med 2014;7:4322-6.

56. Funahashi T, Matsuzawa Y. Adiponectin and the cardiometabolic syndrome: an epidemiological perspective. Best Pract Res Clin Endocrinol Metab 2014;28:93-106.

57. Dessein PH, Tsang L, Solomon A, et al. Adiponectin and atherosclerosis in rheumatoid arthritis. Mediators Inflamm 2014;2014:358949.

58. Lee S, Kwak HB. Role of adiponectin in metabolic and cardiovascular disease. J Exerc Rehabil 2014;10:54-9.

59. Ding Y, Li S, Ma RL, et al. Association of homeostasis model assessment of insulin resistance, adiponectin, and low-grade inflammation with the course of the metabolic syndrome. Clin Biochem 2015;48:5037.

60. Snel M, Jonker JT, Schoones J, et al. Ectopic fat and insulin resistance: pathophysiology and effect of diet and lifestyle interventions. Int J Endocrinol 2012;2012:983814.

61. Cusi K. Role of obesity and lipotoxicity in the development of nonalcoholic steatohepatitis: pathophysiology and clinical implications. Gastroenterology. 2012;142:711-25.

62. Gaggini M, Morelli M, Buzzigoli E, et al. Non-alcoholic fatty liver disease (NAFLD) and its connection with insulin resistance, dyslipidemia, atherosclerosis and coronary heart disease. Nutrients 2013;5:1544-60.
63. Leamy AK, Egnatchik RA, Young JD. Molecular mechanisms and the role of saturated fatty acids in the progression of non-alcoholic fatty liver disease. Prog Lipid Res 2013;52:165-74.

64. Cerović I, Mladenović D, Ješić R, et al. Alcoholic liver disease/nonalcoholic fatty liver disease index: distinguishing alcoholic from nonalcoholic fatty liver disease. Eur J Gastroenterol Hepatol 2013;25:899-904.

65. Friedman LS. Liver, biliary tract and pancreas disorders. In: Papadakis MA, McPhee SJ, editors. Current medical diagnosis and treatment. New York:Mc Graw Hill; 2016. p. 663-720.

66. Chavez-Tapia NC, Rosso N, Tiribelli C. Effect of intracellular lipid accumulation in a new model of non-alcoholic fatty liver disease. BMC Gastroenterol 2012;12:20.

67. Mladenović D, Ninković M, Aleksić V, et al. The effect of calorie restriction on acute ethanol-induced oxidative and nitrosative liver injury in rats. Environ Toxicol Pharmacol 2013;36:296-302.

68. Jorgačević B, Mladenović D, Ninković M, et al. Dynamics of oxidative/ nitrosative stress in mice with methionine-choline-deficient diet-induced nonalcoholic fatty liver disease. Hum Exp Toxicol 2014;33:701-9.

69. Stanković MN, Mladenović DR, Duričić I, et al. Time-dependent changes and association between liver free fatty acids, serum lipid profile and histological features in mice model of nonalcoholic fatty liver disease. Arch Med Res 2014;45:116-24.

70. Osborn O, Olefsky JM. The cellular and signaling networks linking the immune system and metabolism in disease. Nat Med 2012;18:363-74.

71. Juonala M, Magnussen CG, Berenson GS, et al. Childhood adiposity, adult adiposity, and cardiovascular risk factors. N Engl J Med 2011;365:1876-85.

72. Radosavljević T, Todorović V, Šikić B, et al. Insulin-like growth factor-I in rats with portcaval shunting. Period Biolog 2004;106:403-10.

73. Radosavljević T, Todorović V, Nikolić I, et al. Gastrin (G) and enetrochromaffin-like (ELC) cells in the stomach portcaval-shunted rats. A radioimmunological, immunocitochemical and ultrasound study. Acta Veterin 2005;55:23-30.

74. Westley RL, May FE. A twenty-first century cancer epidemic caused by obesity: the involvement of insulin, diabetes, and insulin-like growth factors. Int J Endocrinol 2013;2013:632461.

75. Harris MF. The metabolic syndrome. Aust Fam Physician 2013;42:5247.

76. Murphy R, Carroll RW, Krebs JD. Pathogenesis of the metabolic syndrome: insights from monogenic disorders. Mediators Inflamm 2013;2013:920214.

77. Qatanani M, Tan Y, Dobrin R, et al. Inverse regulation of inflammation and mitochondrial function in adipose tissue defines extreme insulin sensitivity in morbidly obese patients. Diabetes 2013;62:855-63.

78. Grattagliano I, Palmieri VO, Portincasa P, et al. Oxidative stress-induced risk factors associated with the metabolic syndrome: a unifying hypothesis. J Nutr Biochem 2008;19:491-504.

79. Ma ZA, Zhao Z, Turk J. Mitochondrial dysfunction and $\beta$-cell failure in type 2 diabetes mellitus. Exp Diabetes Res 2012;2012:703538.

80. Vučević D, Mladenović D, Ninković M, et al. Influence of aging on ethanol-induced oxidative stress in digestive tract of rats. Hum Exp Toxicol 2013;32:698-705.

81. Vučević D, Mladenović D, Ninković M, et al. The effects of caloric restriction against ethanol-induced oxidative and nitrosative cardiotoxicity and plasma lipids in rats. Exp Biol Med (Maywood) 2013;238:1396-405.

82. Stanković M, Mladenović D, Ninković M, et al. Effects of caloric restriction on oxidative stress parameters. Gen Physiol Biophys 2013;32:277-83.

83. Young LH. Diet-induced obesity obstructs insulin signaling in the heart. Am J Physiol Heart Circ Physiol 2010;298:H306-7.

84. Jornayvaz FR, Shulman GI. Diacylglycerol activation of protein kinase $\mathrm{C} \varepsilon$ and hepatic insulin resistance. Cell Metab 2012;15:574-84. 